\title{
An Experimental Study of Clay Swelling Phenomenon by Carbonic Acid Injection in Clay Sandstone: Implication for $\mathrm{CO}_{2}$ Injection
}

\author{
Sugeng Riyono ${ }^{1}$, Ucok W.R. Siagian ${ }^{1}$, Hasian P. Septoratno Siregar ${ }^{1} \&$ Asep K. Permadi ${ }^{1}$ \\ ${ }^{1}$ Petroleum Engineering Study Program, Institut Teknologi Bandung, Jalan Ganesha No. 10, Bandung 40132, \\ Indonesia \\ Correspondence: Sugeng Riyono, Petroleum Engineering Study Program, Institut Teknologi Bandung, Jalan \\ Ganesha No. 10, Bandung 40132, Indonesia. E-mail: sugengrtm77@gmail.com; \\ sugengriyono@lemigas.esdm.go.id
}

$\begin{array}{lcc}\text { Received: March 30, } 2018 & \text { Accepted: April 10, } 2018 & \text { Online Published: April 30, } 2018 \\ \text { doi:10.5539/mas.v12n5p106 } & \text { URL: https://doi.org/10.5539/mas.v12n5p106 }\end{array}$

The research is financed by LEMIGAS R\&D Center for Oil and Gas Technology, Jakarta, Indonesia

\begin{abstract}
Significant portion of $\mathrm{CO}_{2}$ is dissolved in reservoir brine during $\mathrm{CO}_{2}$-Enhanced Oil Recovery. Dissolved $\mathrm{CO}_{2}$ forms an acidic environment which could modify rock-fluid interaction. One of the phenomena that could happen due to this interaction is clay swelling which may affect enhanced oil recovery performance.

Several experiments were conducted in a number of sandstone core samples, i.e. Imbibition test, Core flood test, Conductivity test, and $\mathrm{pH}$ measurement. Imbibition test was conducted to evaluate $\mathrm{CO}_{2}$-saturated brine (approached with carbonic acid) performance toward oil recovery during five days measurement compared with brine imbibition performance. Moreover, core flood experiment was run to determine the effect of dissolved $\mathrm{CO}_{2}$ in brine on injection in sandstone. This is simulated by injecting brine (base case) followed by carbonic acid under $68.3{ }^{\circ} \mathrm{C}$. Thus, conductivity and $\mathrm{pH}$ of the imbibed fluids (before $\&$ after running imbibition test) were measured to justify occurrence of cation exchange.

Interpretation of imbibition test indicated that imbibing carbonic acid, at $\mathrm{pH}$ value of about four, resulted in loss of oil recovery about $15 \%$ compared with brine due to formation damage caused by clay swelling as sandstone contains clay. The existence of this phenomenon was confirmed by flow resistance at low $\mathrm{pH}$ in core sample which was higher than that in brine. This apparent plugging was expected due to severe clay swelling. Meanwhile, the existence of such phenomenon was also clarified with conductivity and $\mathrm{pH}$ measurement as there was a great amount of cation exchange.

It can be inferred from this study that the rock-fluid interaction from $\mathrm{CO}_{2}$-saturated brine can result in adverse effect, such as injectivity problem and loss of recovery. This finding must be considered in planning $\mathrm{CO}_{2} \mathrm{EOR}$ operations, especially when facing condition of watered out oil zone.
\end{abstract}

Keywords: $\mathrm{CO}_{2}$-saturated brine, acidic environment, clay swelling, injectivity issue

\section{Introduction}

Carbon dioxide $\left(\mathrm{CO}_{2}\right)$ injection in the formations is one of several proposed methods for enhanced oil recovery. There are various typical operations of this injection in the oil industry, such as CCS (Carbon Capture and Storage), WAG (Water Alternating with Gas), $\mathrm{CO}_{2}$-Foaming, Miscible Injection, Immiscible Injection, CWI (Carbonated Water Injection), and Huff \& Puff. Through those processes, many physical and chemical processes are known to occur both during and after $\mathrm{CO}_{2}$ injection, including diagenetic chemical reactions and associated permeability changes.

Variability in rock types responses suggests that $\mathrm{CO}_{2}$ injection will induce changes in intrinsic rock properties such as porosity, permeability and wettability. This is due to coupled physical and chemical processes that occur during the interaction between $\mathrm{CO}_{2}$ and rock minerals. Other potential phenomenon that may happen include severe formation damage due to clay reactivity that can be attributed to $\mathrm{pH}$ reduction from dissolved $\mathrm{CO}_{2}$ in brine.

Moreover, this study mainly investigates clay problem phenomenon under supercritical $\mathrm{CO}_{2}$ phase in $\mathrm{CO}_{2}$ injection 
into sandstone reservoir. It is interesting to investigate this phenomenon since substantial amount of $\mathrm{CO}_{2}$ is also dissolved in brine during injection. In spite of argued benefit, the swelling of clay can mechanically 'expulse' residual oil from the pore as also happens in low salinity water flood mechanism Nasralla et al [10]. On the other hand, the swelling of clay or migrated clay could also reduce the pore size and in turn permeability impairment which on severe case could lead to lack of $\mathrm{CO}_{2}$ performance.

The focus of this study is to get better understanding of formation damage caused by clay swelling during $\mathrm{CO}_{2}$ flooding that may affect EOR performance in typical $\mathrm{CO}_{2}$ applications; such as such as CCS, injection in watered out oil reservoir, CWI, WAG, and Huff \& Puff; through experimental observation. Those practices are conditions of clay reactivity occurrence as $\mathrm{CO}_{2}$ mostly exposed to water/brine and is dissolved into water/brine, acidizing the water/brine environment. Furthermore, investigation of the phenomenon is mainly focused on clay type of kaolinite and montmorillonite as they tend to disperse and swell respectively due to aqueous solution and acidic environment. Also, their structures (composition of octahedral and tetrahedral sheet in a packet) are different from each other and simpler than other clay type.

According to $\mathrm{CO}_{2}$ phase envelope, $\mathrm{CO}_{2}$ will behave as supercritical fluid above its critical temperature, $87.98^{\circ} \mathrm{F}$, and its critical pressure, $1071 \mathrm{psi}$. Hence, $\mathrm{CO}_{2}$ will be formed as supercritical state at reservoir condition, in average The injected $\mathrm{CO} 2$ is partially miscible with brine (up to $1.6-2.6 \%$ mole of $\mathrm{CO}_{2}$ can dissolve in brine with 0.01 to $0.03 \% \mathrm{NaCl}$ ) [Bando et all] and can be calculated by using Duan \& Sun equation (2003) as a function of pressure, temperature, and salinity [Duan et al]. The solubility of $\mathrm{CO} 2$ in water/brine will increase due to increase in pressure and decrease in high temperature and high salinity (due to salting out) [Bando \& Green].

Schaeff and Sigfusson et al reported that the created acidity can achieve significant level of $\mathrm{pH}$ value with range of 3-4 measured at reservoir condition. This change in acidity will occur as an increase in the amount of $\mathrm{CO} 2$ being injected into a reservoir system that makes $\mathrm{CO} 2$ being accumulated to dissolve (i.e. Carbon Capture \&Storage and Huff \& Puff activities).

As injection is initiated in sandstone reservoir, it is interesting to evaluate interaction between acidic solutions being formed and bearing formation, especially clay minerals. The severity of clay damage is not only caused by structure layer existing in the mineral (related to contact area), but also by the type and amount of exchangeable cation (Mungan, 1989). For instance, Na-montmorillonite swells more than Ca-montmorillonite because the Ca cation is strongly adsorbed compared with $\mathrm{Na}$ cation as the mineral is hydrated in aqueous media; according to Roger's work (1963). Based on preceding observation by Reed (1977), he stated that severity of clay swelling is a function of cation type. He mentioned that the most to least damage, causing permeability impairment, cation is $\mathrm{H}+>\mathrm{Na}+>\mathrm{Ca}++$ in a medium of mica with cation of $\mathrm{K}+$ (illustrated in Figure 1) [Civan, Faruk]. This is because ion $\mathrm{K}+$ exchanges with a larger cation.

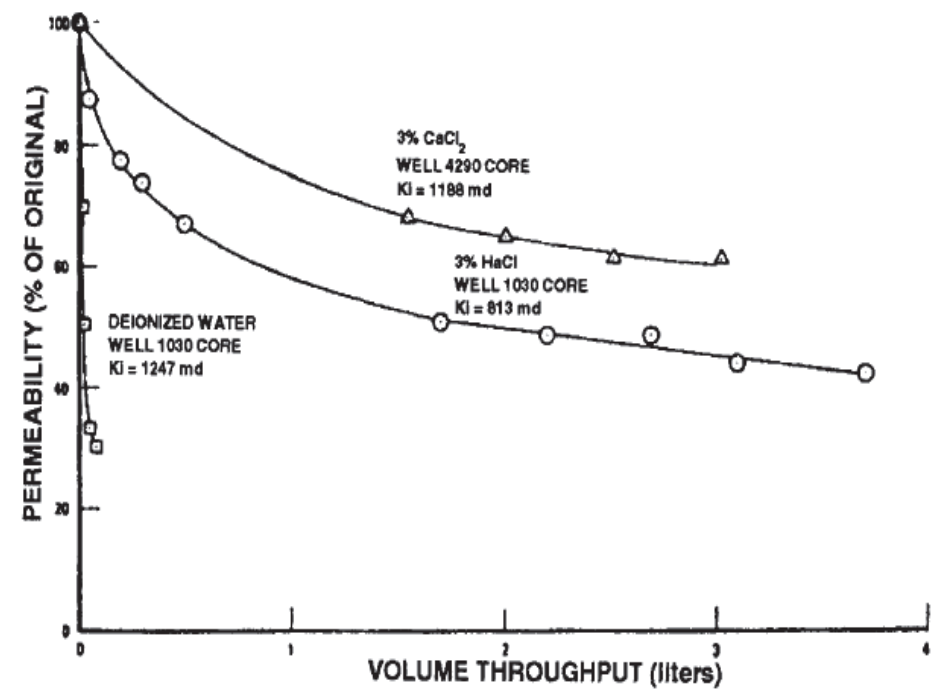

Figure 1. Reed study (1977) of comparison of the permeability damages [2]

Meanwhile, Grim (1942) determined the order of replaceability of common cation in clay from most to least easy as follows [2], 
$\mathrm{Li}^{+}>\mathrm{Na}^{+}>\mathrm{K}^{+}>\mathrm{Rb}^{+}>\mathrm{Cs}^{+}>\mathrm{Mg}^{++}>\mathrm{Ca}^{++}>\mathrm{Sr}^{++}>\mathrm{Ba}^{++}>\mathrm{H}^{+}$

\section{Method}

The examination is conducted in several samples of artificial sandstone core. As $\mathrm{CO}_{2}$ can be dissolved in water, the test was conducted by applying carbonic acid $\left(\mathrm{H}_{2} \mathrm{CO}_{3}\right.$, as a product of $\mathrm{CO}_{2}$ solubility reaction) into all core samples. The solution of carbonic acid was made by titrating chloride acid $(\mathrm{HCl}, \mathrm{pH}$ value of 1$)$ with natrium carbonate $\left(\mathrm{Na}_{2} \mathrm{CO}_{3}, \mathrm{pH}\right.$ value of 12). The concentration of solution being formed has $\mathrm{pH}$ value of about 4 . This $\mathrm{pH}$ was chosen to examine problem that was caused in condition of maximum concentration being achieved in typical practice. The details of ion composition of the solution being made are shown in Table 1.

Table 1. Cation composition of acid solution

\begin{tabular}{ll}
\hline Cation Ion & Amount (ppm) \\
\hline $\mathrm{H}^{+}$ & 88 \\
$\mathrm{Na}^{+}$ & 500 \\
\hline
\end{tabular}

Before conducting the tests, the tested core samples were prepared by saturating brine of natrium chloride $(\mathrm{NaCl})$ with concentration of $500 \mathrm{ppm}$ under nearly vacuum condition (during 4 hours). The use of $500 \mathrm{ppm} \mathrm{NaCl} \mathrm{was}$ meant to make the same experimental condition to all experiments. That value was determined based on product in composing carbonic acid solution. Then, they were pressed forcibly to fill up oil sample to core samples using core flood apparatus at temperature of $68.3^{\circ} \mathrm{C}$ and confined pressure of $100 \mathrm{psi}$, until no brine is produced. After the cores had been filled with oil and brine, these cores were soaked for one day to ensure pore of the cores are fully saturated.

Composition and characteristics of each core samples are shown in

Table 2 and

Table 3 .

Table 2. Core sample composition

\begin{tabular}{lc}
\hline Mineralogy & Weight Percentage (\%) \\
\hline Quartz & 80.4 \\
Kaolinite & 2.8 \\
Montmorillonite & 2.8 \\
K-Feldspar & 14 \\
\hline
\end{tabular}

Table 3. Core Sample Characteristic

\begin{tabular}{lccccc}
\hline Sample & $\mathrm{D}(\mathrm{cm})$ & $\mathrm{H}(\mathrm{cm})$ & $\mathrm{K}(\mathrm{mD})$ & Porosity $(\%)$ & $\mathrm{S}_{\mathrm{oi}}($ fraction $)$ \\
\hline L3 & 2.51 & 3.11 & 215.91 & 24.02 & 0.61 \\
L7 & 2.52 & 3.24 & 151.97 & 23.40 & 0.69 \\
L10 & 2.51 & 3.24 & 185.25 & 24.91 & 0.43 \\
\hline
\end{tabular}

Within this study, observation methods being exhibited were spontaneous imbibition and injectivity test using core flood apparatus (both were under constant salinity) to investigate performance of carbonic acid (as a product of $\mathrm{CO}_{2}$ solubility in water) in term of recovery and flow resistance. As to clay swelling evaluation due to cation exchange, conductivity and $\mathrm{pH}$ of imbibed fluid effluent were also observed. The details for those methods are explained further as follows.

\subsection{Spontaneous Imbibition}

This method compared oil recovery of core samples with different acidic environment and imbibed fluid in a static condition. The L-3 and L-7 samples were chosen to conduct this test according to the amount of initial oil saturation of each sample which was almost the same. L-3 core was imbibed with carbonic acid solution with pH value of 4 . On the other hand, brine water $(\mathrm{NaCl} 500 \mathrm{ppm})$ was used to imbibe L-7 core as a control volume. After all 
samples were already prepared, the samples were soaked in imbibition apparatus with temperature of $68.3^{\circ} \mathrm{C}$ (mimicking reservoir condition) during 5-days. Oil produced from both samples were examined regularly for 6 hours every day with measurement period of 30 minutes in the first day, every hour in the second day, and every two-hour for other days.

\subsection{Core Flood Experiment}

This method was applied for L-10 core sample by applying carbonate acid with $\mathrm{pH}$ value of 4 in flooding scenario for this sample. Constraints, used in performing the tests, were injection speed of $0.3 \mathrm{cc} / \mathrm{minute}$ (according to rule of thumb of $1 \mathrm{ft} /$ day frontal velocity flooding), confining pressure of $100 \mathrm{psi}$ and temperature of $68.3{ }^{\circ} \mathrm{C}$ (mimicking the reservoir condition).

Implemented flooding scenario of this method was flooding sample with brine (until there is no more produced oil, indicated by constant pressure), then flooded it with carbonate acid with the same amount of injected PV as brine injection. This flooding series was meant to evaluate restriction flow whether injecting carbonic acid would give flow resistance change compared with injecting brine. Measurement of flow resistance, being indicated by pressure, was carried out every 5 minutes. The schematic of core-flood apparatus is shown in

Figure 2 .

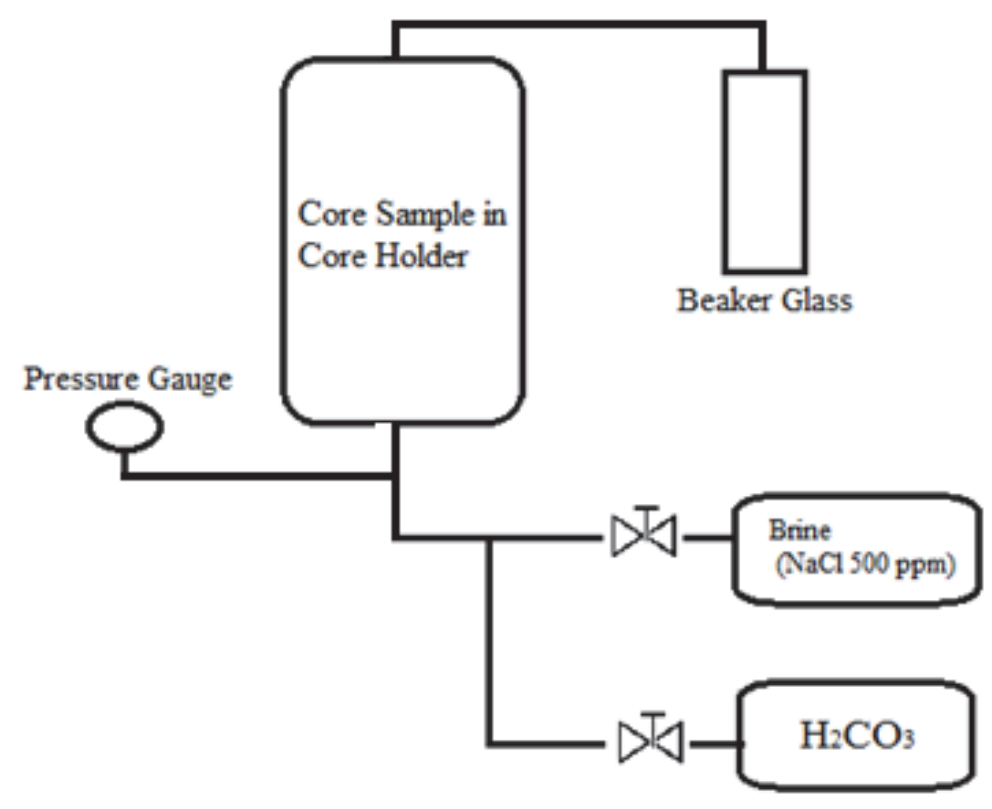

Figure 2. Scheme of core flood apparatus

\subsection{Conductivity and $\mathrm{pH}$ Measurement}

The conductivity of imbibed fluids, which consisted of $\mathrm{pH}-4$ solution and brine, was measured using conductivity apparatus under different condition of imbibed fluids, before and after imbibition test. This test was meant to evaluate occurrence of ionic (cation) alteration fluid during imbibition test. The measurement was conducted by putting the measurement probe to be soaked into several imbibed fluids. The probe must be soaked until top mark and should be prevented from attaching chamber. This measurement was done ten times to ensure observation data consistency and conducted under room temperature.

Besides that, $\mathrm{pH}$ value of imbibed fluids (before and after imbibition test being held) was also measured. The measurement was performed at room temperature condition. This test also was conducted by soaking the probe of $\mathrm{pH}$ meter after the apparatus had been calibrated for measurement of each sample. This measurement was meant to convince that ionic change occurred. 


\section{Results \& Discussions}

\subsection{Spontaneous Imbibition Test \& Core flood Experiment

$$
\text { ime (nours) }
$$

Figure 3 shows oil recovery of L-3 and L-7 core samples that resulted from spontaneous imbibition process under different acidic environment. From the figure, recoverable oil in imbibition process of brine water is higher (by difference of about $15 \%$ ) than that process of carbonic acid with $\mathrm{pH}$ value of 4 . The cause of this phenomenon is expected to be induced by severe clay swelling at low $\mathrm{pH}$ environment. The increase of d-spacing of clay mineral, basically, occurs in both core samples, being clarified in conductivity test discussion, due to applied aqueous solution that is below critical salt solution according to Mohan \& Fogler (1988) study. However, this severity occurred due to a great amount of cation being exchanged between solution and mineral. As explanation of Reed (1977) study, core sample applied with acid solution (L-3) will undergo severe swelling due to a huge amount of $\mathrm{H}^{+}$ion. A lot of mineral's cations will diffuse out of the mineral (according to Fick's Law) and will be replaced by that ion until steady state, in terms of ionic balance, is achieved.

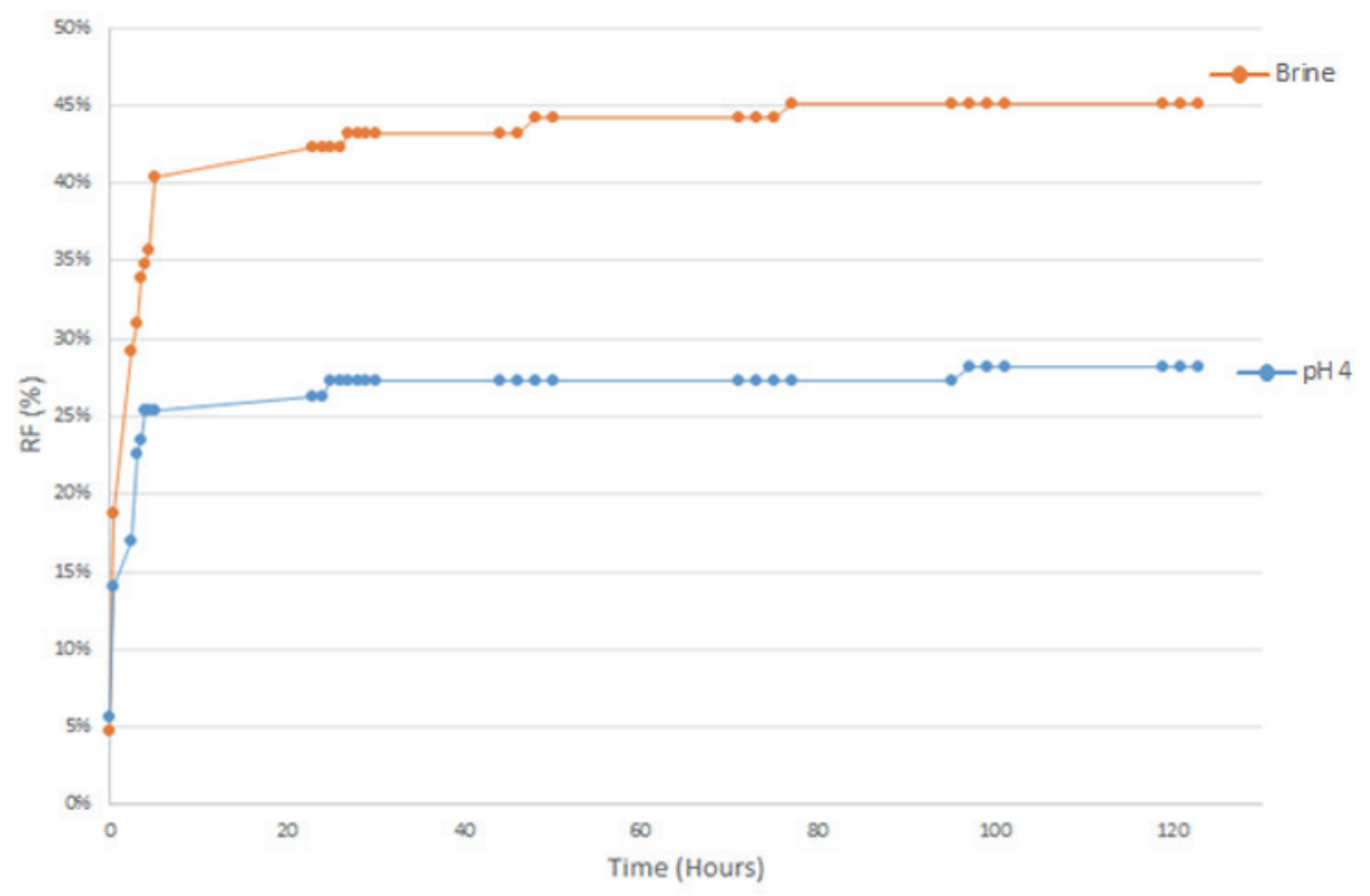

Figure 3. Recovery factor of imbibition test by imbibing brine and carbonic acid solution

The occurrence of this term is also depicted in injectivity test (Figure 4). As carbonic acid solution injection is initiated, fluid flow tends to be more resistant than in injection of brine. It is clearly shown in the graph that there is a pressure increase after injecting acid solution, around 6 psi under steady condition. This flow resistance is mainly attributed to shrinking of pore throat in core sample due to clay swelling. Swelled of migrated clay (Kaolinite type) also leads the flow resistance as it plugs the pore throat. 


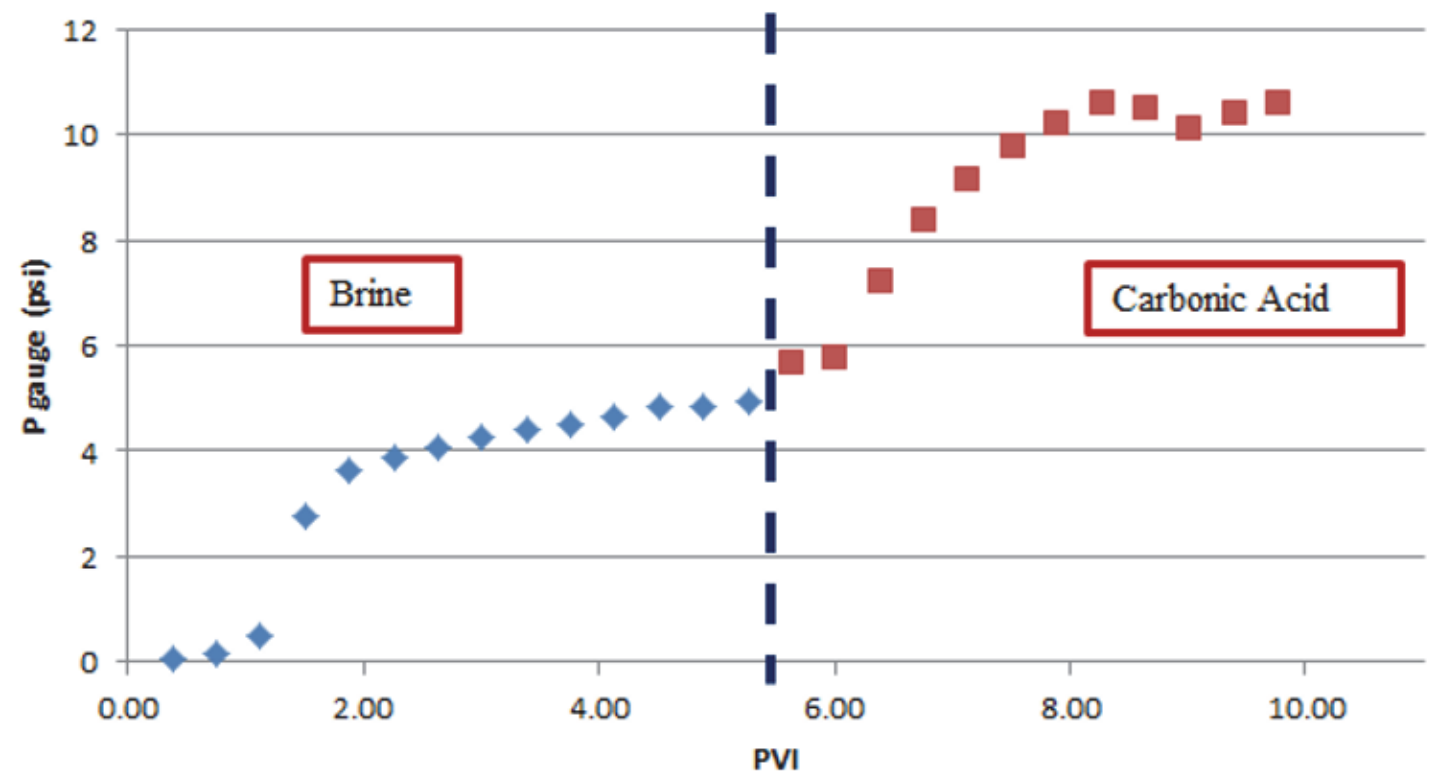

Figure 4. Result of injectivity test on L-10 by injecting brine, thus carbonic acid

\subsection{Conductivity \& $p H$ Evaluation}

Measurement of conductivity of each imbibed fluid, being used for imbibition test, are shown in the following tables (Table 4 \& 5).

Table 4. Result of conductivity test of imbibed fluid of brine

\begin{tabular}{lcccc}
\hline \multirow{2}{*}{$\begin{array}{l}\text { Number of } \\
\text { Measurement }\end{array}$} & \multicolumn{2}{c}{ Before Imbibition } & \multicolumn{2}{c}{ After Imbibition } \\
\cline { 2 - 5 } & $\begin{array}{c}\text { Conductivity } \\
(\text { mSiemen) }\end{array}$ & $\begin{array}{c}\text { Temperature } \\
(\text { deg C) }\end{array}$ & $\begin{array}{c}\text { Conductivity } \\
(\text { mSiemen })\end{array}$ & $\begin{array}{c}\text { Temperature } \\
(\text { deg C })\end{array}$ \\
\hline 1 & 2.4 & 25.8 & 3.42 & 25.5 \\
2 & 3.01 & 25.8 & 3.33 & 25.6 \\
3 & 3.1 & 25.8 & 3.38 & 25.6 \\
4 & 3.07 & 25.8 & 3.38 & 25.6 \\
5 & 3.05 & 25.8 & 3.37 & 25.5 \\
6 & 3.08 & 25.8 & 3.37 & 25.6 \\
7 & 3.07 & 25.8 & 3.37 & 25.5 \\
8 & 3.07 & 25.8 & 3.34 & 25.5 \\
9 & 3.03 & 25.8 & 3.37 & 25.5 \\
10 & 3.09 & 25.8 & 3.36 & 25.5 \\
Average & 3.00 & 25.80 & 3.37 & 25.54 \\
\hline
\end{tabular}

Table 5. Result of conductivity test of imbibed fluid of carbonic acid solution

\begin{tabular}{lcccc}
\hline \multirow{2}{*}{$\begin{array}{l}\text { Number of test } \\
\text { Measurement }\end{array}$} & \multicolumn{2}{c}{ Before Imbibition } & \multicolumn{2}{c}{ After Imbibition } \\
\cline { 2 - 5 } & $\begin{array}{c}\text { Conductivity } \\
\text { (mSiemen) }\end{array}$ & $\begin{array}{c}\text { Temperature (deg } \\
\text { C) }\end{array}$ & $\begin{array}{c}\text { Conductivity } \\
\text { (mSiemen) }\end{array}$ & $\begin{array}{c}\text { Temperature (deg } \\
\text { C) }\end{array}$ \\
\hline 1 & 16.75 & 25.9 & 34.5 & 25.4 \\
2 & 16.96 & 25.9 & 34.6 & 25.5 \\
3 & 16.4 & 25.9 & 34.3 & 25.5 \\
4 & 16.79 & 25.9 & 34.6 & 25.6
\end{tabular}




\begin{tabular}{lcccc}
5 & 16.88 & 25.9 & 34.6 & 25.6 \\
6 & 16.05 & 25.8 & 34.8 & 25.5 \\
7 & 16.13 & 25.8 & 34.6 & 25.5 \\
8 & 16.46 & 25.8 & 33 & 25.6 \\
9 & 16.68 & 25.8 & 34.8 & 25.6 \\
10 & 16.81 & 25.8 & 34.7 & 25.5 \\
Average & 16.59 & 25.85 & 34.45 & 25.53 \\
\hline
\end{tabular}

From those evaluations, it could be inferred that cation exchange really happened. The great change of the value of conductivity, as expected, occurs in carbonic acid solution. Although parameter evaluation value of brine imbibition also changes, it is not significant compared with acid solution because the core samples have been saturated with fluid having the same characteristics as injected fluid. Hence, there is only a little change to reach an ionic balance condition.

Whereas, alteration of $\mathrm{pH}$ for each imbibed fluid is shown below.

Table 6. Result of $\mathrm{pH}$ measurement of imbibed fluid

\begin{tabular}{lcc}
\hline Imbibed Fluid & pH Before Imbibition & pH After Imbibition \\
\hline Brine $(\mathrm{NaCl} 500 \mathrm{ppm})$ & 7.46 & 7.81 \\
$\mathrm{H}_{2} \mathrm{CO}_{3}(\mathrm{pH}-4)$ & 4.69 & 8.01 \\
\hline
\end{tabular}

As ion $\mathrm{H}^{+}$replace a great number of cation in mineral, this cation (usually alkali or metal ion) will give a great change in fluid conductivity term. Besides that, the cation also will give an increase value of $\mathrm{pH}$ as it interacts with water to form a base solution, whether it is strong base solution, weak base solution, or both.

\section{Conclusions}

In conclusion, performance of dissolved $\mathrm{CO}_{2}$ in water during injection (approached by injecting carbonic acid with $\mathrm{pH}$ value of 4) leads to loss of performance. This is indicated by loss of oil recovery at static condition (using imbibition) and higher flow resistance than base case (injecting brine). This happens as a result of interaction between dissolved $\mathrm{CO}_{2}$ in water and clay mineral. This interaction leads to severe clay swelling phenomenon as large amount of cation are being exchanged.

Furthermore, this investigation of this clay swelling phenomenon can be improved by conducting integrated SEM and NMR Analysis in capturing the evidence of clay swelling. Not only that, but further core flood test also should be conducted in investigating the phenomenon and evaluating recovery performance by varying $\mathrm{pH}$ in injection acid. Thus, pure $\mathrm{CO}_{2}$ injection in watered oil core should be carried out in order to mimic field practice. The advance evaluation of effluent water in core flood test should be conducted in order to evaluate cation exchange level as a function of time, thus determining clay exchange capacity for each clay type and clay formation rate attributed to reactivity of clay type and cation diffusion rate.

\section{Acknowledgements}

Our highest gratitude is presented to LEMIGAS R\&D Center for Oil and Gas Technology and OGRINDO-ITB for helping in facilitating to conduct experiment, discussing, and giving a new insight within this topic.

Nomenclature

$$
\begin{aligned}
& \text { D : Diameter of core sample }[\mathrm{cm}] \\
& H \quad \text { : Height of core sample [cm] } \\
& K \quad \text { : Permeability [mD] }
\end{aligned}
$$

\section{References}

Bando, S., Takemura, F., Nishito M., Hikara, E., \& Akai, M. (2003). Solubility of $\mathrm{CO}_{2}$ in aqueous solution of $\mathrm{NaCl}$ at (30 to 60) ${ }^{\circ} \mathrm{C}$ and (10 to 20) MPa. Journal of Chemical \& Engineering Data, 48, 576-579.

Civan, F. (2000). Reservoir Formation Damage (Fundamentals, Modelling, Assessment, and Mitigation). Houston, Texas: Gulf Publishing Company. 
Duan, Zh. H., Rui, S., Chen, Zh., \& I-Ming, Ch. (2005). An Improved Model for The Calculation of $\mathrm{CO}_{2}$ Solubility in Aqueous Solutions Containing $\mathrm{Na}^{+}, \mathrm{K}^{+}, \mathrm{Ca}^{2+}, \mathrm{Mg}^{2+}, \mathrm{Cl}^{-}$, and $\mathrm{SO}_{4}^{2-}$. ELSEVIER.

Gangopadhyay, S. (2013). Engineering Geology. Oxford University Press India.

Green, D. W., \& Willhite, G. W. (1998). Enhanced Oil Recovery. Texas: Henry L. Doherty Memorial Fund of AIME, Society of Petroleum Engineers.

Grim, R. E. (1953). Clay Mineralogy. New York: McGraw Hill Book Co.

Grim, R. E. (1968). Clay Mineralogy. International Series in the Earth and Platenary Science. F. Press, ed. New York: McGraw Hill Book.

Hendrick, S. B., \& Jefferson, M. E. (1938). Structure of Kaolin and Talc - Pyrophyllite Hydrate Sand their Bearing on Water Sorption of The Clay. Am. Mineral., 23, $863-875$.

Iglauer, S. et al. (2014). Permeability Evolution in Sandstone due to Injection of $\mathrm{CO}_{2}$-saturated Brine or Supercritical $\mathrm{CO}_{2}$ at Reservoir Condition. Australia, Curtin University: Australia.

Karpinski, B., \& Szkodo, M. (2015). Clay Minerals - Mineralogy and Phenomenon of Clay Swelling in Oil \& Gas Industry. Poland: Gdansk University of Technology.

Nasralla, R. A., Mohammed, B. A., Hisham, A., Nasr-El, Din, Texas, A., \& M University, all SPE Members. (2011). Efficiency of Oil Recovery by Low Salinity Water Flooding in Sandstine Reservoir. This paper was presented at the SPE Western North American Regional Meeting, in Anchorage, Alaska, USA, 7 - 11 May 2011. Society of Petroleum Engineers.

Otaibi, Al., Fawaz, M., Al Khaidi, Mohammed, H., Funk, Jim, J., Shen, Shouwen, X., \& Saudi, A. (2012). New Insights into Clay Swelling: Supercritical $\mathrm{CO}_{2}$ Interaction with Montmorillonite. This paper was presented at the Eighteenth SPE Improved Oil recovery Symposium held in Tulsa, Oklahoma, USA, 14 - 18 April 2012. Society Petroleum Engineers.

Schaeff, H. T., McGrail, B. P. (2004). Direct Measurement of pH in $\mathrm{H}_{2} \mathrm{O}-\mathrm{CO}_{2}$ brine mixtures to supercritical conditions. Proceedings of the $7^{\text {th }}$ International Conferrence on Greenhouse Gas Control Technologies (GHGT-7), Vancouver, Canada.

Sigfusson, B., Gislason, S. R., Matter, J. M., Stute, M., Gunnlaugsson, E., ... Oelkelrs, E. H. (2015). Solving the carbon-dioxide buoyancy challenge; The design and field testing of a dissolved $\mathrm{CO}_{2}$ injection system. International Journal of Greenhouse Gas Control Technologies, in press.

Tombacz, E., \& Marta, S. (2006). Surface Charge Heterogeneity of Kaolinite in Aqueous Suspension in Comparison with Montmorillonite. Hungary: ELSEVIER.

\section{Copyrights}

Copyright for this article is retained by the author(s), with first publication rights granted to the journal.

This is an open-access article distributed under the terms and conditions of the Creative Commons Attribution license (http://creativecommons.org/licenses/by/4.0/). 